\title{
PEMAKNAAN MIN AL-DHULUMAT ILA AL-NUR DALAM USAHA TRANSFORMATIF LEMBAGA PENDIDIKAN ISLAM
}

\author{
Moh. Muslim ${ }^{1}$
}

\begin{abstract}
The effort to develop an Islamic educational institution can not only be built on the concept of Aqliyah theory, but also based on the concept of God revelation. One of the explicit messages of God revelation is the phrase min adhulumatilaannur (from the darkness to the lightness). Implicitly, this phrase implies a transformation process from dhulumat (darkness) to an-nur (lightness). The process of transformation needs to be elaborated intact and holistic, how to interpret it; which will be formulated into the implementative formulation of the phrase.

The phrase min al dhulumat ila an-nur conceptually there are three dimensional meaning that includes: 1). Textual, textual meaning of min al-dhulumatilaannur is from the darkness to the lightness, 2). Contextual, contextual meaning of min al-dhulumatilaannur; there are some interpretations from the interpreter whose essence is changing from disbelief to the faith, from apostasy to the faith, from ignorance to knowledge, and 3). Reconceptualization, there is a relevance of the concept min aldhulumatilaannur with the management of education,that related to the transformation process that must be done to accept a change.

Actualization of transformation can be done on some basic elements of education, i.e., students, teachers, headmasters/ managers, supervisors, employees and parents.
\end{abstract}

Keywords: Min Al-DhulumatIlaAl-Nur, Transformative, Islamic Educational Institution

\begin{abstract}
ABSTRAK
Usaha pengembangan lembaga pendidikan islam tidak hanya di dasarkan pada konsep teori aqliyah semata, akan tetapi juga mendasarkan pada konsep wahyu ilahiyah. Salah satu pesan tersurat dari wahyu ilahi adalah kalimat min adhulumat ila an nur. Secara tersirat, lafadz tersebut mengandung makna adanya proses transformasi dari dhulumat menuju an nur. Adanya proses transformasi tersebut perlu di elaborasi lebih mendalam secara utuh dan holistik bagaimana pemaknaanya yang pada akhirnya akan dapat dirumuskan menjadi rumusan-rumusan implementatatif dari kalimat tersebut.
\end{abstract}

1 Dosen Fakultas Agama Islama Universitas Islam Malang (FAI-UNISMA) 
Secara konsep kalimat min al-dhulumat ila annur ada tiga dimensi pemaknaan yang meliputi: 1). Tekstual, makna tekstual dari min al-dhulumat ila annur adalah dari kegelapan menuuju cahaya, 2). Kontekstual yakni makna kontekstual dari min al-dhulumat ila annur ada beberapa penafsiran dari mufasir yang intinya adalah perubahan dari kekafiran menuju keimanan, dari kesesatan menuju kebenaran, dari kebodohan menuju berilmu, dan 3). Rekonseptualisasi yakni adanya relevansi dari konsep min al-dhulumat ila annur dengan pengelolaan pendidikan yaitu berhubungan dengan adanya proses transformasi yang harus dilakukan untuk terjadinya sebuah perubahan.

Aktualisasi transformasi dapat dilakukan kepada beberapa unsur pokok pendidikan, yaitu, siswa, guru, kepalasekolah/manajer, pengawas, karyawan dan orang tua.

Kata kunci : Min Al-Dhulumat Ila Al-Nur, Transformatif, Lembaga Pendidikan Islam

\section{A. PENDAHULUAN}

Penciptaan manusia sebagai makhluk paling sempurna dari makhluk yang lain dituntut untuk mengembangkan berbagai potensi yang dimilikinya. Dalam rangka mengembangkan berbagai potensi tersebut, maka dapat dilakukakan melalui sebuah wadah yang berupa pendidikan dengan berbagai jalur, jenjang dan jenisnya. Melalui wadah pendidikan inilah maka akan mampu membentuk watak, karakter, tingkah laku atau hal lain yang berhubungan dengan diri dan kepribadianya.

Dalam rangka mengawal dan menghantarkan pada manusisia sempurna sebagaimana tertuang dalam tujuan pendidikan nasional yaitu mencerdaskan kehidupan bangsa dan mengembangkan manusia Indoensia seutuhnya, yaitu manusia yang beriman dan bertaqwa terhadap Tuhan Yang Maha Esa dan berbudi pekerti luhur, memiliki pengetahuan dan keterampilan, kesehatan jasmani dan rohani, kepribadian yang mantap dan mandiri serta rasa tanggung jawab kemasyarakatan dan kebangsaan, maka sudah seharusnya pendidikan islam ikut berpartisipasi aktif guna terwujud dan tercapainya tujuan tersebut.

Dengan adanya pendidikan, maka akan timbul dalam diri seseorang untuk berlomba-lomba dan memotivasi diri kita untuk lebih baik dalam segala aspek kehidupan. Pendidikan merupakan salah satu syarat untuk lebih memajukan pemrintah ini, maka usahakan pendidikan mulai dari tingkat SD sampai pendidikan di tingkat Universitas.

Bila dilihat dari tujuan pendidikan nasional, maka orientasi pendidikan tidak hanya mengoptimalkan potensi manusia dari ranah kognitif semata, akan tetapi juga meningkatkan ranah afektif dan psikomotorik, baik yang bersifat intelektual, emosional dan spiritual, berupa jasmaniah maupun ruhaniah.

Berpijak dari hal di atas, maka pendidikan Islam memiliki peran vital 
dan central guna memberikan berbagai rumusan strategis implementatif bagi keberlangsungan dan tercapainya tujuan tersebut.

Untuk itulah maka pendidikan islam harus mampu dan mempersiapkan penataan (manage) kelembagaan yang betul-betul dapat mensupport atau mendukung keberlangsung proses pendidikan guna tercapainya tujuan pendidikan dengan efektif dan efisien.

Dengan adanya pengelolaan (management) kelembagaan yang baik, maka akan dapat melakukan berbagai langkah-langkah strategis sistematis dalam menata lembaga pendidikan yang berkualitas dan berdaya saing di tengah-tegah masyarakat.

Pendidikan islam yang di dalam praktiknya tiada hanya sekedar mendasarkan setiap langkahnya pada kemampuan akal pikiran saja, akan tetapi juga mendasarkan paka tuntunan wahyu ilahi, maka sudah seharusnya bagi lembaga islam untuk mengelaborasi berbagai pesan yang tersurat maupun tersirat berkenaan dengan upaya peningkatan mutu pengelolaan lembaga pendidikan.

Salah satu pesan tersurat dari wahyu ilahi adalah kalimat min al dhulumat ila an-nur. Secara tersirat, lafadz tersebut mengandung makna adanya proses transformasi dari dhulumat menuju an nur. Adanya proses transformasi tersebut perlu di elaborasi lebih mendalam secara utuh dan holistik bagaimana pemaknaanya yang pada akhirnya akan dapat dirumuskan menjadi rumusan-rumusan implementatatif dari kalimat tersebut.

Apa dan bagaimanakah min ad-dhulumat ila an-nur dalam pendidikan Islam terkait dengan konseptualisasi dan aktulisasinya maka akan akan dikupas lebih mendalam dalam makalah ini.

\section{B. PEMAKAAN KONSEPTUAL MIN AL-DHULUMAT ILA AN NUR}

Redaksi kalimat min ad-dhulumat ila an-nur di dalam Al-Qur'an disebutkan sebanyak tujuh kali dalam enam surah, yaitu QS. Al-Baqarah: ayat 257, QS. Al-Maidah: ayat 16, QS. Ibrahim: ayat 1 dan 5, QS. Al-Ahzab: ayat 43, QS. Al-Hadid: ayat 9, QS. At-Thalaq: ayat 11. Kebalikan dari konsep ini adalah konsep min an-nur ila ad-adhulumat yang di dalam Al-Qur'an disebut hanya sekali, yaitu pada QS. Al-Baqarah: 257 (Qomar, 2013).

Untuk melihat pesan yang terkandung di dalam lafdz min ad-dhulumat ila an-nur yang terdapat pada masing-masing ayat tersebut, maka perlu di kaji dari sudut pandang makna tektual (harfi), kontekstual (maknawi) dan rekonstruksi konsep min adzulumat ilan an nur.

\section{Makna Tekstual}

Sebagai usaha untuk melakukan proses pemaknaan kontekstual terhadap kalimat min ad-dhulumat ila an-nur maka perlu di telusuri lebih jauh dan mendalam terhadap kalimat tersebut. 
a. QS. Al-Baqarah ayat 257

"Allah Pelindung orang-orang yang beriman; Dia mengeluarkan mereka dari kegelapan (kekafiran) kepada cahaya (iman). Dan orang-orang yang kafir, pelindung-pelindungnya ialah syaitan, yang mengeluarkan mereka daripada cahaya kepada kegelapan (kekafiran). Mereka itu adalah penghuni neraka; mereka kekal di dalamnya.

b. QS. Al-Maidah ayat 16

"Dengan kitab itulah Allah menunjuki orang-orang yang mengikuti keridhaan-Nya ke jalan keselamatan, dan (dengan kitab itu pula) Allah mengeluarkan orang-orang itu dari gelap gulita kepada cahaya yang terang benderang dengan seizin-Nya, dan menunjuki mereka ke jalan yang lurus".

c. QS. Ibrahim ayat 1 dan 5

"Alif, laam raa. (Ini adalah) Kitab yang Kami turunkan kepadamu supaya kamu mengeluarkan manusia dari gelap gulita kepada cahaya terang benderang dengan izin Tuhan mereka, (yaitu) menuju jalan Tuhan Yang Maha Perkasa lagi Maha Terpuji”. (QS. Ibrahim: 1)

"Dan sesungguhnya Kami telah mengutus Musa dengan membawa ayatayat Kami, (dan Kami perintahkan kepadanya): "Keluarkanlah kaummu dari gelap gulita kepada cahaya terang benderang dan ingatkanlah mereka kepada hari-hari Allah". Sesunguhnya pada yang demikian itu terdapat tanda-tanda (kekuasaan Allah) bagi setiap orang penyabar dan banyak bersyukur". (QS. Ibrahim: 5)

d. QS. Al-Ahzab ayat 43

"Dialah yang memberi rahmat kepadamu dan malaikat-Nya (memohonkan ampunan untukmu), supaya Dia mengeluarkan kamu dari kegelapan kepada cahaya (yang terang). Dan adalah Dia Maha Penyayang kepada orang-orang yang beriman".

e. QS. Al-Hadid ayat 9

"Dialah yang menurunkan kepada hamba-Nya ayat-ayat yang terang (AlQuran) supaya Dia mengeluarkan kamu dari kegelapan kepada cahaya. Dan sesungguhnya Allah benar-benar Maha Penyantun lagi Maha Penyayang terhadapmu".

f. QS. At-Thalaq: ayat 11

"(Dan mengutus) seorang Rasul yang membacakan kepadamu ayatayat Allah yang menerangkan (bermacam-macam hukum) supaya Dia mengeluarkan orang-orang yang beriman dan beramal saleh dari kegelapan kepada cahaya. Dan barangsiapa beriman kepada Allah dan mengerjakan amal yang saleh niscaya Allah akan memasukkannya ke dalam surga-surga yang mengalir di bawahnya sungai-sungai; mereka kekal di dalamnya selama-lamanya. Sesungguhnya Allah memberikan rezei yang baik kepadanya". 
Dari terjemah di atas maka dapat di simpulkan bahwa dari tujua ayat yang di dalamnya terdapat kalimat min ad-dhulumat ila an-nur memiliki arti kegelapan kepada cahaya. (Warson, 1997: 882-1474).

\section{Makna Kontekstual}

Berkenaan dengan kalimat min ad-dhulumat ila an-nur beberapa ahli tafsir (mufasir) telah menafsirkan kalimat min ad-dhulumat ila an-nur, diantaranya adalah ibnu katsir yang menafsirkan

$$
\text { من ظلمات الكفر والشك والريب إلى نور الحق الواضح الجلي المبين السهل المنير }
$$

(Ibn Katsir, 186), al maraghi menafsirkan yang di maksud dengan dlulumat adalah jalan kekufuran dan kesubhatan yang bertetangan dengan agama. (AlMaraghi, 261).

Dari beberapa ayat tentang kalimat min al-dhulumat ila an nur yang terdapat di dalam al Quran, Ash-Shabuni. menafsirkan bahwa Allah penolong orang-orang mukmin, menjaga, dan mengurus urusan mereka. Dia mengeluarkan mereka dari kegelapan kekafiran dan kesesatan menuju cahaya iman dan petunjuk. Pada surah Al-Maidah ayat 16, ia menafsirkan bahwa Allah mengeluarkan mereka dari kegelapan kekafiran menuju cahaya iman melalui taufik dan kehendak-Nya. Pada surah Ibrahim ayat 1, ia menafsirkan bahwa hal yangdimaksud adalah untuk mengeluarkan manusia dari kegelapan, kebodohan, dan kesesatan menuju cahaya ilmu dan iman. Pada surah Ibrahim ayat 5, ia menafsirkan bahwa Allah telah mengeluarkan Bani Israil dari kegelapan kebodohan dan kekafiran menuju cahaya iman dan tauhid. Pada surah Al-Ahzab ayat 43, ia menafsirkan bahwa hal yang dimaksud adalah untuk menyelamatkanmu dari kesesatan menuju petunjuk dan dari kegelapan kedurhakaan menuju cahaya ketaatan dan iman. Pada surah Al-Hadid ayat 9, ia menafsirkan bahwa hal yang dimaksud adalah untuk mengeluarkan kamu dari kegelapan kekafiran menuju cahaya iman. Pada surah At-Thalaq ayat 11, ia menafsirkan bahwa hal yang dimaksud adalah untuk mengeluarkan orang-orang Mukmin yang bertaqwa (muttaqin) dari kegelapan menuju cahaya iman dan ilmu.

Adapun mufasir lainnya seperti Az-Zamakhsari, At-Thabari, dan AlMaraghi menafsirkan kalimat min ad-dhulumat ila an-nur sebagai berikut: pada surah Ibrahim ayat 1 az-Zamakhsari menafsirkan kata ad-dhulumat dan an-nur sebagai lambang bagi 'kesesatan' dan 'petunjuk' dengan izin Tuhan mereka atas kemudahan-Nya memperoleh izin yang melepaskan belenggu atau penutup. Hal itu memberikan mereka dari kebaikan dan taufik, at-Thabari menafsirkannya sebagai petunjuk bagi mereka dari kegelapan, kesesatan, dan kekafiran menuju cahaya iman dan memperlihatkan kepada orang yang bodoh dan buta tentang jalan lurus dan petunjuk. Sedangkan 
Al-Maraghi menafsirkannya sebagai maksud untuk menyelamatkan manusia dari kegelapan, kesesatan, dan kekafiran menuju cahaya iman serta memperlihatkan jalan lurus dan petunjuk kepada orang yang bodoh dan buta (Qomar, 2013: 81).

Pada surah Al-Baqarah ayat 257, QS. Al-Maidah ayat 16, QS. Ibrahim ayat 1, QS. Al Ahzab ayat 43, QS. Al-Hadid ayat 9, dan At-Thalaq ayat 11, kalimat min ad-dhulumat ila an-nur didahului oleh kata 'tukhriju' yaitu fi'il mudharik (kata kerja yang menunjukkan sedang berlangsung). 'Tukhriju' atau 'yukhriju' jika disambung dengan isim dhomir (kata ganti), isim dzahir (kata benda), isim maushul (kata penghubung), maupun didahului oleh 'akhrij' yaitu fi'il amr (kata perintah) yang disambung dengan gabungan isim dzahir dan isim dhamir yakni qaumaka (kaummu) seperti tertulis dalam surah Ibrahim ayat 5, ternyata jika dikumpulkan memiliki banyak makna. Kata $a d-$ dhulumat bisa bermaksud kebodohan, kekafiran, kesesatan, atau kedurhakaan. Sedangkan kata an-nur bisa bermakna iman, tauhid, ilmu, petunjuk, jalan lurus, atau ketaatan.

Konsep min ad-dhulumat ila an-nur bukan sekedar konsep dari AlQur'an yang tekstual normative semata, akan tetapi konsep tersebut sangat relevan bagi usaha pengembangan pendidikan dalam perspektif manajemen pendidikan Islam.

Dengan adanya konsep tersebut, dapat mengilhami adanya sebuah pemahaman bahwa didalam proses pengelolaan pendidikanmaka tidak bisa serta merta menyamakan kondisi peserta didik, guru, karyawan, maupun kepala sekolah/madrasah/pimpinan PTAI, dan pengawas, diposisikan dengan makna ad-dhulumat (kebodohan, buta, kekafiran, kedurhakaan, dan kesesatan), melainkan konsep tersebut perlu ditiru atau diadaptasi dan diaktualisasikan menjadi proses tranformasi yang sangat ideal, yaitu dari $a d-$ dhulumat menjadi an-nur (Qomar, 2013: 81-82).

Proses transformasi inilah yang sedianya menjadi perhatian husus bagi pelaku pendidikan untuk melakukan berbagai upaya perbuhana dari sesuatu yang pada awalnya destruk tif menjadi konstruktif, negative menjadi positif. Transformasi akan dapat berjalan dengan optimal apabila di pengaruhi oleh kesadaran manajer atau kesadaran individu yang terlibat dalam proses.

Dari uraian diatas, maka dapat di rumuskan sebuah kesimpulan bahwa makna tersirat dari min al-dhulumat ila an nur adalah proses transformasi. Transformasi adalah sebuah proses perubahan secara berangsur-angsur sehingga sampai pada tahap ultimate, perubahan yang dilakukan dengan cara memberi respon terhadap pengaruh unsur eksternal dan internal yang akan mengarahkan perubahan dari bentuk yang sudah dikenal sebelumnya melalui proses menggandakan secara berulang-ulang atau melipatgandakan (Rahmi, 2014: 58). 
Secara leksikal terdiri dari dua suku kata yaitu kepemimpinan dan transformatif. Kata transformatif memiliki arti sebagai "perubahan rupa (bentuk, sifat, fungsi, dan lain sebagainya)", bahkan ada juga yang mengartikan sebagai segera membuat sesuatu perubahan total baik dalam bentuk, penampilan, karakter, dan seterusnya (make a through or dramatic change in the form, appearance, character, etc) (Efendi, 2007: 1). Sedangkan secara semantik kata transformatif berinduk pada kata "to transform" yang didefinisikan dengan "mentransformasikan" atau "mengubah sesuatu menjadi bentuk lain yang berbeda," misalnya mentransformasikan visi menjadi realita, panas menajdi energi, potensi menjadi aktual atau sesuatu yang bersifat negatif destruktif menjadi sesuatu yang bersifat positif konstruktif.

Oleh sebab itu, transformatif mengandung makna sifat-sifat yang dapat mengubah sesuatu menjadi bentuk lain, misalnya mengubah energi potensial menjadi energi aktual atau motif berprestasi menjadi prestasi riil (Danim, 2005: 54). Hal ini bisa dimaknai sebgai suatu landasan pemaknaan kata transformatif atau tranformasional tersebut, sebab kata transformasi sendiri mengandung dua kata dasar yaitu " trans" yang berarti melintasi (across); malampaui (beyond) dan kata "form" yang memiliki arti bentuk; rupa; penampilan. Sehingga, kata transformasi mengandung makna perpindahan (proses melampaui) dari bentuk (penampilan) yang satu ke bentuk yang lain. Sehingga kepemimpinan transformatif adalah sebuah gaya kepemimpinan yang didalamnya mengandung suatu proses dimana pimpinan dan para bawahanya berusaha untuk mencapai tingkat moralitas dan motivasi yang lebih tinggi. Artinya ia mencoba untuk membangun kesadaran para bawahanya dengan menyerukan cita-cita yang besar dan moralitas yang tinggi seperti kejayaan, kebersamaan, dan kemanusiaan. Sedangkan para pengikut pemimpin transformatif akan termotivasi untuk melakukan hal yang lebih baik untuk mencapai sasaran organisasi (Rahmi, 2014: 59).

Perubahan yang ada dilakukan memiliki tujuan yang jelas dan terencana dalam rangka perubahan kearah yang positif. Sepertia halnya dalam proses realisasi dari sebuah visi menjadi kenyataan yang riil (Danim, 2006: 218219). Perubahan menuntut adanya sebuah percepatan dalam pelaksanaannnya (Klark, 1994: 1). Uraian di atas menggambarkan bahwa proses perubahan merupakan suatu proses merubah dari satu bentuk/model ke bentuk yang lain dengan melihat berbaagai wilayah garapan, baik yang brsifat profit maupu non profit guna meningkatkan mutu suatu organisasi atau lembaga.

\section{Rekonstruksi konseptual}

Dari berbagai pemaknaan yang sudah dipaparkan oleh para ahli tafsir yang kemudian dipahami bahwa makna kontekstual dari min al-dhulumat il an nur yang ada keterkaitannya dengan strategi manajemen pendidikan 
islam adalah, bahwa makna dari kalimat tersebut bukan hanaya sekedar perpindahan dari kafir menjadi beriman, dari gelap menuju ke terang, akan tetapi lebih dari iyu kalimat tersebut memiliki makan yang sangat mendalam yakni adanya proses transformasi dalam usaha perubahan tersebut. Makna esensi transformasi ini menjadi fondasi utama bagi pengelolaan lembaga pendidikan. Mengelola lembaga pendidikan harus di dasari adanya usaha transformasi Keara positif konstruktif bagi keberlangsungan lembaga.

Bila dilihat dari redaksi yang ada di dalam ayat-ayat di atas, maka menurut hemat penulis pemaknaan kalimat min al-dhulumat ila an nur dengan transformati semata, maka masih belum menggambarkan pemaknaan secaa utuh. Pemberian makna tersebut tentu dapat dipengaruhi dari keutuhan kalimat tersebut di dalam ayat. Apabila kalimat min al-dhulumat ila annur di gabung dengan satu rangkaian ayat maka makna yang tersirat tidak hanya transformasi semata, akan tetapi menurut penulis makna yang lebih sesuai adalah transformasi pasif, artinya bahwa adanya tranformasi yang ada sangat dominan di tentuka oleh kebraan Tuhan di dalam perubahannya, sehingga manusia tidak bersifat aktif, tapi pasif.

Keberadaan manusia pada posisi transformasi pasif ini selanjutnya di bedakan menjadi transformative pasif sadar (TPS) dan transformative pasif tidak sadar (TPTS). Sebagai gambaran kongrit dari transformasi pasif sadar dan transformasi pasif tidak sadar adalah bila ada orang/lembaga yang dia sudah mendapatkan ilmu dan dia mengetahui bahwa hal itu adalah salah, akan tetapi dia tidak mampu mengendalikan dirinya untuk tidak melakukan. Gambaran seperti itu disebut dengan transformative pasif sadar, sedangkan apabila orang tersebut belum pernah belajar sehingga dia tidak memiliki ilmunya dan kemudian melakukan sebuah pelanggaran maka disebut transformative pasif tidak sadar.

Dari kedua transformative pasif di atas, maka akan terjadi tranformasi apabila Tuhan memberikan petunjuk (hidayah) sehingga ada proses tranformasi secara alamiyah (nativisme/jabariyah). Sebagaimana pernyataan Allah dalam Surah Al Baqoroh ayat 272 dan 284 sebagai berikut:

"Bukanlah kewajibanmu menjadikan mereka mendapat petunjuk, akan tetapi Allah-lah yang memberi petunjuk (memberi taufiq) siapa yang dikehendaki-Nya. Dan apa saja harta yang baik yang kamu nafkahkan (di jalan allah), maka pahalanya itu untuk kamu sendiri. Dan janganlah kamu membelanjakan sesuatu melainkan karena mencari keridhaan Allah. Dan apa saja harta yang baik yang kamu nafkahkan, niscaya kamu akan diberi pahalanya dengan cukup sedang kamu sedikitpun tidak akan dianiaya (dirugikan)" (QS. A1 Baqarah: 272) 
"Kepunyaan Allah-lah segala apa yang ada di langit dan apa yang ada di bumi. Dan jika kamu melahirkan apa yang ada di dalam hatimu atau kamu menyembunyikan, niscaya Allah akan membuat perhitungan dengan kamu tentang perbuatanmu itu. Maka Allah mengampuni siapa yang dikehendaki-Nya dan menyiksa siapa yang dikehendaki-Nya; dan Allah Maha Kuasa atas segala sesuatu”. (QS. Al Baqarah: 284).

Sedangkan kalimat min adulumat ila an nur akan memiliki pemahaman yang berbeda bila ia berdiri sendiri dan tidak dipengaruhi oleh kalimat sebelum atau sesudahnya. Maka disinilah akan muncul proses tranformatif aktif (TA) dimana manusi dengan potensi akalnya akan melakukan sebuah langkah strategis untuk menuju dan melakukan perubahan di dalam menjalani kehidupannya. Dengan pemaknaan ini, maka memaknai kalimat dlulumat dengan kafir, bodoh atau sesat semata menjadi kurang sempurna, karena ada makna lain yaitu kegelapan.

Dalam kamus besar Bahasa Indonesia bodoh berarti tidak lekas mengerti; tidak mudah tahu atau tidak dapat (mengerjakan dan sebagainya), kafir yaitu orang yang tidak percaya kepada Allah dan rasul-Nya; sesat yaitu tidak melalui jalan yang bena dan gelap berarti tidak ada cahaya; kelam; tidak terang (KBBI).

Bila mendasarkan pada arti kata tersebut, maka dapat di gunakan untuk memaknaai kata dhulumat bahwa . dhulumat bila di artikan dengan kafir, bodoh dan sesat, maka hal itu menunjukan posisi manusia sudah mengetahui sesuatu (berilmua) namun tidak berjalan sesuai dengan yang dikehendaki sehingga proses tranformativ yang berlangsung pada kondisi seperti ini yaitu dengan rekonstruktif transformative (RT) yaitu sebuah proses tranformasi yang berusaha untuk membangun ulan strategi manajemen yang sudah ada dan diadakan rekontruksi kembali ke arah perbaikan. Pola rekonstruktif transformative ini seirama dengan konsep aliran naturalime dalam aliran pendidikan. Sebagaimana di katakana oleh J.J. Rousseaue yang muncul pada abad ke-18. Nature dalam bahasa latin memiliki makna Alam pelopor aliran pendidikan naturalism yang berpendapat setiap anak yang baru dilahirkan pada hakikatnya memiliki pembawaan baik. Namun pembawaan baik yang terdapat pada setiap anak itu akan berubah sebaliknya karena dipengaruhi oleh lingkungan. Lingkungan tersebut dapat berupa, lingkungan keluarga, lingkungan sekolah, atau lingkungan masyarakat di sekitar dimana anak tumbuh dan berkembang.

Rousseaue mengatakan, anak yang terlahir dalam keadaan baik tersebut biarkan berkembang secara alami. Ini artinya bahwa perkembangan anak yang dipengaruhi oleh pendidikan apakah pendidikan di rumah, di 
sekolah, maupun di masyarakat sebagai urun rembuk orang-orang dewasa malah akan merusak pembawaan anak yang baik. Dia juga mengatakan "segala sesuatu adalah baik ketika ia baru keluar dari alam, dan segala sesuatu menjadi jelek manakala ia sudah berada di tangan manusia."

Sedangkan bila bermakna gelap, artinya gelap, gelap disini tidak bermakna bahwa kondisinya dalam kesesatan akan tetapi melambangkan pada titik nol yang masih belum terisi dengan sesuatu apapun. Posisi dari nol inilah yang mengharuskan adanya konstruk baru atau awal untuk melakukan sebuah transformasi. Pemahaman ini menggambarkan bahwa dlulmumat dalam konteks ini adalah titik awal untuk menggapai an nur dengan sebuah usaha dan proses tranformatif dari dasar. Proses transformasi yang demikian dapat dikatakan sebagai proses strategi manajemen kontruktif transformative (KT). pahami bahwa proses transformative yang harus dikembangkan adalah bersifat konstruktif, artinya dalam konteks strategi manajemen pendidikan yaitu transformative yang dilakukan berangkat dari awal dan dari dasar, sehingga betul-betul melangkah dari dasar dalam mengkonstruknya. Proses tranformatif dari dapat di konstruk sesuai dengan tujuan yang di canangkan serta pemahaman ini sejalur dengan hadis Nabi SAW sebagai berikut:

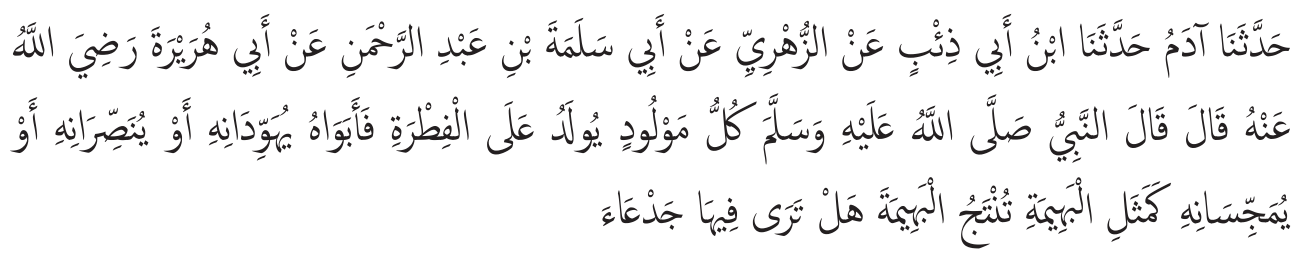

"Telah menceritakan kepada kami Adam telah menceritakan kepada kami Ibnu Abu Dza'bi dari Az Zuhriy dari Abu Salamah bin 'Abdurrahman dari Abu Hurairah radliallahu 'anhu berkata; Nabi Shallallahu'alaihiwasallam bersabda: "Setiap anak dilahirkan dalam keadaan fithrah. Kemudian kedua orang tuanyalah yang akan menjadikan anak itu menjadi Yahudi, Nashrani atau Majusi sebagaimana binatang ternak yang melahirkan binatang ternak dengan sempurna. Apakah kalian melihat ada cacat padanya?" (Shohih Bukhari, 1296)

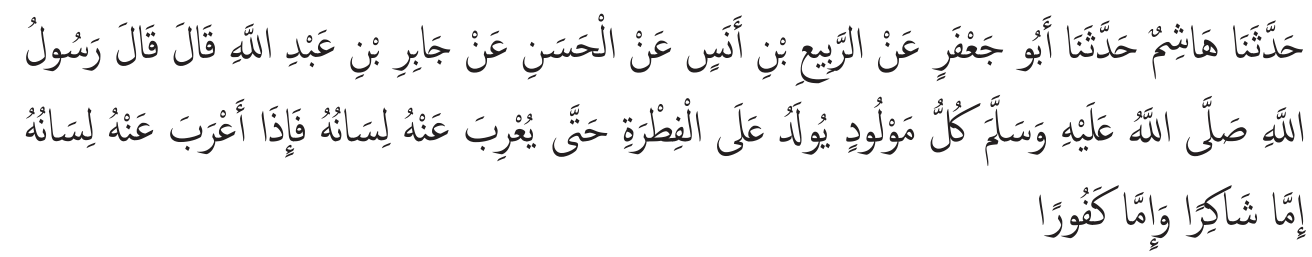

"Telah bercerita kepada kami Hasyim telah bercerita kepada kami Abu Ja'far dari Ar-Robi' bin Anas dari Al Hasan dari Jabir bin Abdullah berkata; Rasulullah shallallahu'alaihi wasallam bersabda: "Setiap 
anak dilahirkan di atas fithrah (Islam), hingga lisannya menyatakannya (mengungkapkannya), jika lisannya telah mengungkapkannya, dia nyata menjadi orang yang bersyukur (muslim) atau bisa juga menjadi orang yang kufur".(Shohih Muslim, 14277)

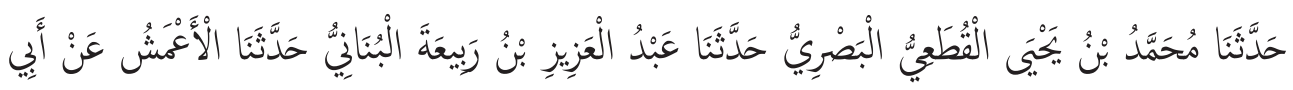

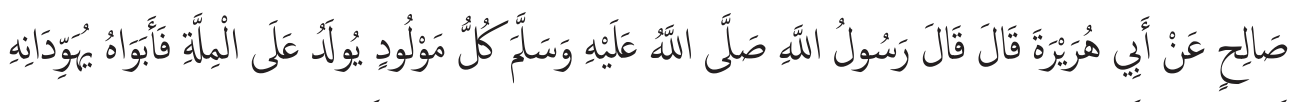

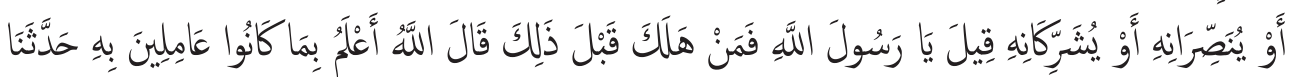

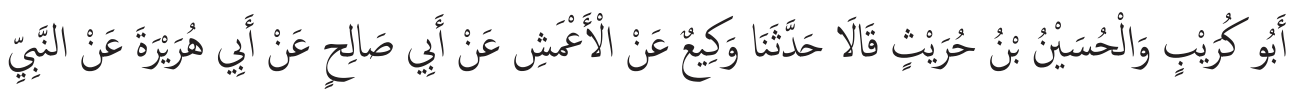

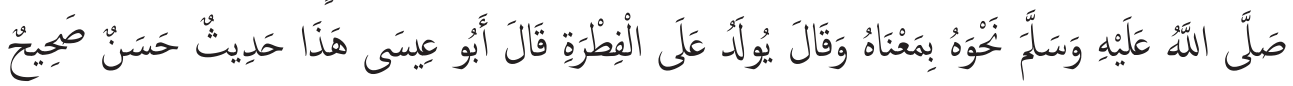

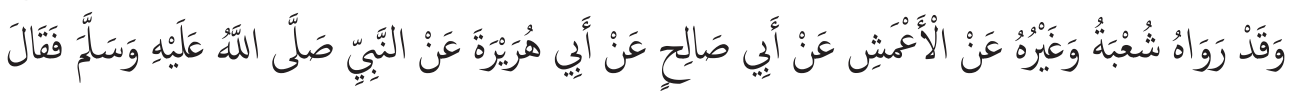

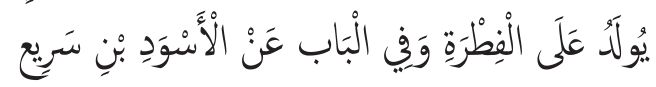

"Telah menceritakan kepada kami Muhammad bin Yahya Al Qutha'i Al Bashri; telah menceritakan kepada kami 'Abdul 'Aziz bin Rabi'ah Al Bunani; telah menceritakan kepada kami Al A'masy dari Abu Shalih dari Abu Hurairah dia berkata; Rasulullah shallallahu 'alaihi wasallam bersabda: "Setiap anak dilahirkan di atas al millah (agama fithrahnya, Islam), namun, kedua orangtuanyalah yang menjadikannya Yahudi atau Nasrani, atau menjadikannya seorang yang musyrik." Kemudian ditanyakanlah pada beliau, "Wahai Rasulullah, lalu bagaimanakah dengan yang binasa sebelum itu? " belaiu menjawab: "Allah-lah yang lebih tahu terhadap apa yang mereka kerjakan." Telah menceritakan kepada kami Abu Kuraib dan Al Husain bin Huraits keduanya berdua berkata; telah menceritakan kepada kami Waki' dari Al A'masy dari Abu Shalih dari Abu Hurairah dari Nabi shallallahu 'alaihi wasallam sepertinya dan dengan makna yang sama pula dan beliau bersabda: "Dilahirkan dalam keadaan fithrah." Abu Isa berkata; Ini adalah hadits Hasan Shahih. Dan hadits ini telah diriwayatkan pula oleh Syu'bah dan selainnya dari Al A'masy dari Abu Shalih dari Abu Hurairah dari Nabi Nabi shallallahu 'alaihi wasallam, ia pun menyebutkan; "Dilahirkan dalam keadaan fithrah." Hadits semakna juga diriwayatkan dari Al Aswad bin Sari’2.(Tirmidzi No. 2064)

Rekonstruksikonsep diatas, menjelaskan bahwakonsep transformative dibagi menjadi dua yaitu Transformatif pasif (TP) dan Transformatif aktif (TA) dimana masing masing masih dijabarkan lagi, TP meliputi Transformatif

2 Lidwa, sunan tirmidzi, 2064 
Pasif Sadar (TPS) dan Transformatif Pasif Tidak Sadar (TPTS), sedangkan TA meliputi Tranformatif AKtif Rekonstruktif (TAR) dan Transformatif Aktif Konstruktif (TAK).

C. STRATEGI AKTUALISASI KONSEP MIN AL-DHULUMAT ILA $A L$-NUR DALAM LEMBAGA PENDIDIKAN ISLAM

1. Peta Konsep Strategi Mengaktualisasikan Konsep Min Al-Dhulumat Ila Al-Nur (ijtihad penulis)

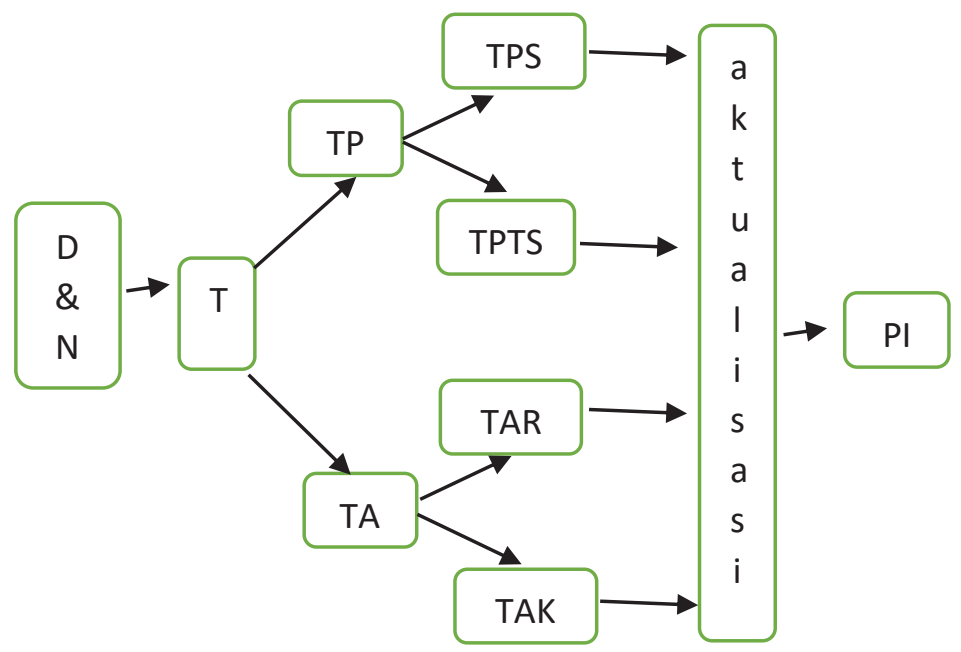

Keterangan

- D \& N : Dlulumat dan An Nur

- $\mathrm{T} \quad$ : Transformatif

- TP : Transformatif Pasif

- TA : Transformatif Aktif

- TPS : Transformatif Pasif Sadar

- TPTS : Transformatif Pasif Tidak Sadar

- TAR : Transformatif Aktif Rekonstruktif

- TAK : Transformatif Aktif Konstruktif

\section{Strategi Mengaktualisasikan Konsep Transformatif Dalam Lembaga} Pendidikan Islam

Dalam pengelolaan organisasi secara modern (termasuk di dalamnya lembaga pendidikan) keberadaan strategi menjadi kebutan pokok yang tidak dapat ditinggal guna mencapa tuan sebuah organisasi. Strategi memiliki arti sesuatu yang di rancang dan disiasati secara cermat agar memebri hasil atau keuntungan . dalam konteks organisasi keberadaan strategi selalu memberikan hasil yang lebih baik. ${ }^{3}$

3 H. Abdullah Halim Usman, Manajemen Strategi Syariah, Jakarta, Zaikrul Hakim, 2015, hal. 20 
Dalam strategi mengaktualisasikan konsep transformative dalam lembaga pendidikan, maka ada beberapa komponen pokok utam, yaitu; siswa, guru, pemimpin/manajer/kepala sekolah, karyawan dan wali murid.

a. Tranformasi pada Siswa :

1. Mentranformasikan keadaan tidak paham menjadi paham.

2. Mentranformasikan kemampuan daya serap materi yang lambat menjadi cepat.

3. Mentranformasikan wawasan yang sempit menjadi wawasan yang luas/komprehensif.

4. Mentranformasikan sikap pasif menjadi inisiatif-kreatif.

5. Mentranformasikan gaya hidup konsumtif menjadi gaya hidup produktif.

6. Mentranformasikan sikap bergantung pada orang lain menjadi sikap mandiri.

7. Mentranformasikan sikap eksklusif menjadi sikap inklutif.

8. Mentranformasikan sikap fanatik menjadi sikap toleran.

9. Mentranformasikan sikap malas menjadi rajin.

10. Mentranformasikan kebiasaan nakal menjadi kebiasaan taat.

11. Mentranformasikan kondisi minder menjadi percaya diri.

12. Mentranformasikan kebiasaan indisipliner menjadi disiplin.

13. Mentranformasikan sikap sulit bergaul menjadi sikap fleksibel dan mampu bergaul.

14. Mentranformasikan kondisi tidak terampil menjadi terampil.

15. Mentranformasikan pemikiran yang beku menjadi pemikiran yang kritis.

b. Tranformasi pada kepribadian pendidik atau guru :

1. Mentranformasikan kebiasaan sekadar mengajar menjadi kebiasaan yang benar-benar mengajar.

2. Mentranformasikan sikap tidak peduli terhadap keberadaan peserta didik menjadi sikap menyelami latar belakang dan problem-problem yang dihadapi peserta didik.

3. Mentranformasikan sikap amatir menjadi sikap professional.

4. Mentranformasikan kebiasaan tidak peduli terhadap perencanaan pembelajaran menjadi kebiasaan menyiapkan perencanaan pembelajaran.

5. Mentranformasikan kebiasaan melestarikan pengetahuan menjadi kebiasaan memburu pengetahuan.

6. Mentranformasikan kebiasaan hanya menyampaikan pengetahuan menjadi kebiasaan menemukan pengetahuan.

7. Mentranformasikan kebiasaan memproteksi pengetahuan menjadi kebiasaan mengembangkan pengetahuan. 
8. Mentranformasikan keadaan kurang kompeten menjadi sangat menguasai tugas-tugas.

9. Mentranformasikan kebiasaan berperan mendominasi pengajaran menjadi beralih kebiasaan memerankan peserta didik secara maksimal dalam kegiatan pembelajaran.

10. Mentranformasikan sikap malas mengajar menjadi bersemangat mengajar.

11. Mentranformasikan kebiasaan indisipliner menjadi sangat disiplin.

12. Mentranformasikan sikap membebani peserta didik menjadi sikap membantu kesulitan yang dialami peserta didik.

13. Mentranformasikan kesan menakutkan menjadi kesan menggairahkan semangat belajar peserta didik.

14. Mentranformasikan sikap membuat jarak dengan peserta didik menjadi sikap yang senantiasaberusaha mendekati peserta didik.

15. Mentranformasikan sikap monoton selama proses pembelajaran menjadi sikap inovatif.

c. Pemimpin/manajer/kepala sekolah

1). tranformasi dikondisikan oleh manajer :

a) Mentranformasikan tradisi bekerja asal-asalan menjadi tradisi bekerja dengan target yang jelas.

b) Mentranformasikan sikap serba menuntut kesejahteraan menjadi sikap serba berprestasi kerja.

c) Mentranformasikan kebiasaan menunggu perintah atasan menjadi kebiasaan berkreasi dan memiliki inisiatif sendiri.

d) Mentranformasikan kecenderungan ideologis menjadi kecenderungan professional.

e) Mentranformasikan kebiasaan banyak berbicara menjadi kebiasaan banyak bekerja.

f) Mentranformasikan kemampuan bekerja hanya secara individual menjadi kemampuan bekerja secara kolektif dalam teamwork.

g) Mentranformasikan kebiasaan bergantung pada orang lain menjadi kebiasaan mandiri.

h) Mentranformasikan pola kerja monoton menjadi pola kerja yang varian-dinamis.

i) Mentranformasikan kecenderungan pada masa lampau menjadi kecenderungan merespons masa depan.

j) Mentranformasikan sikap usil terhadap pekerjaan orang lain menjadi sikap bersemangat menangani pekerjaannya sendiri.

k) Mentranformasikan pola kerja yang boros menjadi pola kerja yang efektif-efisien. 
1) Mentranformasikan respons pasif terhadap pekerjaan yang dihadapi menjadi respons proaktif.

m) Mentranformasikan sikap kerja yang ceroboh menjadi sikap kerja yang teliti dan cermat.

n) Mentranformasikan sikap kerja tanpa berpikir menjadi bekerja dengan menggunakan logika kerja.

o) Mentranformasikan pola hidup konsumtif menjadi pola hidup produktif.

2). tranformasi oleh manajer :

a) Mentranformasikan kecenderungan sektarian menjadi kecenderungan profesional.

b) Mentranformasikan pendekatan politis-ideologis menjadi pendekatan akademik akademik-kultural.

c) Mentranformasikan sikap memihak kelompok tertentu menjadi menyatukan semua kelompok sebagai satu warga besar.

d) Mentranformasikan sikap menampilkan diri sebagai pemimpin golongan menjadi sikap menampilkan diri sebagai pemimpin milik semua golongan.

e) Mentranformasikan kecenderungan membuat faksi-faksi menjadi semangat menjaga keutuhan bawahannya.

f) Mentranformasikan sikap mempertajam persoalan perbedaan (khilafah) menjadi sikap mengalihkan pada persoalan yang strategis.

g) Mentranformasikan kebiasaan otoriter menjadi kebiasaan yang demokratis.

h) Mentranformasikan kebiasaan pengambilan keputusan otoritatif menjadi kebiasaan pengambilan keputusan partisipasif.

i) Mentranformasikan sikap diskriminatif menjadi sikap berbagi secara adil.

j) Mentranformasikan pola-pola kerja birokratis menjadi polapola kerja kolegial.

k) Mentranformasikan kebiasaan memarahi bawahan menjadi kebiasaan memberikan contoh keteladanan.

1) Mentranformasikan kesukaan mengawasi bawahan menjadi kesukaan memfasilitasi mereka.

m) Mentranformasikan ketakutan menghadapi resiko menjadi keberanian mengelola resiko.

n) Mentranformasikan sikap kaku menjadi sikap fleksibel (luwes). 
o) Mentranformasikan sikap membatasi interaksi menjadi sikap mengembangkan interaksi.

p) Mentranformasikan kebiasaan menunggu instruksi atasan menjadi kebiasaan mencari terobosan baru.

d. Tranformasi oleh pengawas :

1. Mentranformasikan kebiasaan mengangkat guru untuk menjadi pengawas dengan melihat dan memilih guru yang memiliki latar belakang pendidikan supervise.

2. Mentranformasikan sikap malas bertugas menjadi rajin bertugas.

3. Mentranformasikan kecenderungan lama dikantor menjadi kecenderungan lama dilapangan.

4. Mentranformasikan sikap menarget amplop (uang) menjadi sikap menargetkan temuan umapan balik (feedback).

5. Mentranformasikan kesukaan memarahi menjadi kesukaan membina atau mengarahkan.

6. Mentranformasikan kesukaan mencari-cari kesalahan menjadi kesukaan mencarikan solusi.

7. Mentranformasikan tindakan yang membebani madrasah dan guru menjadi tindakan yang membantu.

e. Transformasi oleh orang tua

1. mentransformasikan dari tidak peduli menjadi peduli terhadap kebijakan lembaga

2. mentransformasikan dari tidak terlibat menjadi terlibat dalam merumuskan program dan kebijakan lembaga

3. mentransformasikan dari tidak mengontrol menjadi mengontrol terhadap pelaksanaan program dan kebijakan sekolah

4. mentransformasikan dari tidak mendukung menjadi mendukung pelaksanaan belajar mengajar di sekolah.

5. Mentransformasikan dari pasif menjadi berpartisipasi aktif dalam mensosialisasikan kegiatan sekolah di berbagai komunitas.

6. Mentransformasikan dari tidak terlibat menjadi terlibat dalam pelaksanaan program kerja lsekolah

7. Mentransformasikan dari kontribusi pasif menjadi kontribusi aktif dalam memberikan ide/gagasan dalam rangka peningkatan kualitas pembelajaran.

8. Mentransformasikan dari pemakai/konsumen menjadi pemilik atas keberlangsungan lembaga.

\section{PENUTUP}

Secara konsep kalimat min al-dhulumat ila annur ada tiga dimensi pemaknaan yang meliputi: 1). Tekstual, makna tekstual dari min al-dhulumat 
ila annur adalah dari kegelapan menuuju cahaya, 2). Kontekstual yakni makna kontekstual dari min al-dhulumat ila annur ada beberapa penafsiran dari mufasir yang intinya adalah perubahan dari kekafiran menuju keimanan, dari kesesatan menuju kebenaran, dari kebodohan menuju berilmu, dan 3). Rekonseptualisasi yakni adanya relevansi dari konsep min al-dhulumat ila annur dengan pengelolaan pendidikan yaitu berhubungan dengan adanya proses transformasi yang harus dilakukan untuk terjadinya sebuah perubahan.

Aktualisasi transformasi dapat dilakukan kepada beberapa unsur pokok pendidikan, yaitu, siswa, guru, kepalasekolah/manajer, pengawas, karyawan dan orang tua.

\section{DAFTAR PUSTAKA}

UU SISDIKNAS No. 20 tahun 2003

Danim, Sudarwan, 2005, Menjadi Komunitas Pembelajar: Kepemimpinan Transformational dalam Komunitas Organisasi Pembelajaran, Jakarta : Bumi Aksara

Danim, Sudarwan, 2006, Visi Baru Manjemen Sekolah dari Unit Birokrasi ke Lembaga Akademik, Jakarta: Bumi Aksara

Efendi, Tjiptadinata, 2007, Transformasi Diri: Dalam Mengarungi Samudra Kehidupan, Jakarta: Elex Media Komputindo

Klark, Liz, 1994, The Essense Of Change, United Kingdom: Prentis Hall

Qomar, Mujamil, 2013, Strategi Pendidikan Islam, Jakarta : Erlangga

Rahmi, Sri, 2014, Kepemimpinan Transformasional dan Budaya Organisasi, Jakarta: Mitra Wacana Media

Usman, Abdullah Halim, 2015, Manajemen Strategi Syariah, Jakarta, Zaikrul Hakim

Warson, 1997, Kamus al Munawwir, Surabaya: Pustaka Progresif 